\title{
Using ICT in foreign language teaching - the case of secondary schools in Elbasan, Albania
}

\author{
LEONARDA MYSLIHAKA \\ Lecturer of internal University "Aleksander Xhuvani" Elbasan, Albania \\ Humanities faculty, the french branch \\ leomyslihaka@yahoo.it
}

\author{
DOI:10.5901/mjss.2014.v5n19p373
}

\begin{abstract}
This article reflects the situation of the use of information and communications technology (ICT) in the teaching of foreign languages in secondary schools in the city of Elbasan in Albania. We are specifically focused on learning more on how ICT is used and integrated in the teaching / learning of the French language in the secondary schools of the city of Elbasan. We think that the younger generation needs new tools to be more attractive, more motivated and more coherent. For this reason we have undertaken this study in the secondary schools in the city of Elbasan. The paper is focused on three main issues related to the following questions: To what extend is ICT used and integrated in the teaching/learning of foreign languages in secondary schools in the city of Elbasan, Albania? Does its usage facilitate the teaching/learning of the foreign languages?; Do the teachers have the proper qualification and knowledge to use ICT in their teaching practices?; We have carried out several questionnaires and interviews with the main stakeholders and we have also carried out experiments that demonstrate the advantages and disadvantages of using ICT in the teaching/learning of foreign languages, in our case of French as a foreign language in the secondary schools. We will also reflect the factors that promote or inhibit the integration and use of ICT in teaching and all the problems that teachers and students encounter while using ICT.
\end{abstract}

Key words: ICT, teaching / learning, secondary schools , use, formation

\section{Introduction}

The term "Information and communication technologies" is currently used to describe a collection of services, applications and technologies, referring to various devices, which function through networking and telecommunications. For Gerbault J (2002) ICT is defined as "a community of the most advanced technologies used to communicate, share, and address and modify information, asynchronically or synchronically, through the voice, the fixed image or the animated image, and text." Under the same perspective we can find G.L. Baron's and E. Bruillard's definition of ICT in their article, as "composed by audiovisuals on one hand and informatics together with its instruments on the other hand, which administer interactions in distance (...), forming a new area part of the common technologies, which include actions that were previously included in the educational field and in the educational informatics ". Meanwhile, GUICHON N. (2012) in his book defines ICT as "a set of digital technologies, relying on computer use in order to research and disseminate information and communication optimization." In Albania, in the draft on "standards of information and communication technology for teachers" ICT's are defined as: "the totality of electronic means to collect, to store, to process and to present information to users in support of their activities. It consists, among others, of computer systems, electronic office systems and consumer electronics systems. Furthermore, it consists of an information network infrastructure, components of which are: the telephone system, the Internet, fax machines and computers. "

Thus, the notion information and communication technologies universally summarizes "the techniques used in the handling and transmission of information, mainly computers, the internet and telecommunications.". For us, ICT represents the technical union between telecommunications, informatics and audiovisuality. ICT summarizes a set of resources required to manipulate information and especially computers, software and networks necessary to turn, stock, direct, transmit and recapture it. Meanwhile, another problem is noted in the terms "Information and Communication Technologies" and "New Technologies of Information and Communication". Sometimes, we continue to call the ICT "New technologies of information and communication", although fifty years have already passed since the micro-processor began the revolution we witness today. It is true that this label allows us to explicitly refer to advanced technologies relying on computer use to communicate. ICT offer on the one hand a broad range of online clauses, which means, accessible through a communication network (the best known network is undoubtedly the Internet) that enables access to remote computers and servers, and on the 
other, enabling access to resources offline, which means without communicating with a network (floppy, CD-Rom, DVD). In practice, today it is easier to access information, where devices can combine online and offline. According to an article published by Le ticanalyste "Les TIC: qu'est ce que c'est?", beyond the content of the expression "Information and Communication Technologies" it is noted that it is the semantics of the term "technologies" that is the subject of controversy in the scientific literature. Nowadays, the word "technology" is used more and more in its plural form and relies on the adjective "new". The term "new technologies" is necessary to evoke the current technical facilities. (Ruffier Cl., 2006). For most researchers, both in English and in French, the term "technology" does not name a word on technique but it enacts a coherent community technique. We think that the concept of "Information and communication technologies' (ICT) refers to numeric type technological equipment, which can serve as pedagogical tools in teaching. (eg. computers, servers, video projectors, CD-Rom, MP3 reader, USB, DVD, TBI, etc.). Finally, ICT means all kinds of technology that are used to exploit and manipulate information, so there is a combination of Technology with Information and Communication. ICT in education is understood as an implementation of technological equipment and tools in the learning process to record and process information in a digital form.

\section{ICT and the practical tool/equipment:}

ICT by Dieuzeide (1994, p.11), include "instruments carrying messages (images, sounds, characters)" and historically mean three types of technologies in the field of education: audio - visual technologies of the presentation of information (images and sounds), informatics, whose function is to organize and treat information (computer and interaction) and delocalization technologies and transfer of information (internet and digital resources).

Some ICT, as key tools already used in the teaching / learning of foreign languages, are as follows:

- Laboratories, which are of two types: audio laboratories audio and multimedial laboratories.

- Computer rooms (which have replaced foreign language laboratories)

- Multimedia

- Interactive white board (TBI).

- The Internet

- USB

- CD, DVD

- Multifunctional digital cameras

- Video Projector

- MP3 Reader

- Television

- Radio

- Etc.

Thus ICT include all digital technologies (computers, electronic networks, multimedia ...) and also including vision conference, satellite television, videos, tools (computer programs), CD-Roms and the Internet. We will briefly address a few of them:

*The computer: Having a computer in the classroom is an asset to any teacher. With a computer in the classroom, teachers are able to demonstrate a new lesson, new materials, illustrated and show new web pages. The computer in the classroom motivates and provides immediate feedback to students, especially when giving correct answers. Moreover, a computer is patient and non-judgmental, so he gives students motivation to continue learning, and to correct problems that arise during a task. The computer is seen as one of the most necessary technologies in teaching. Until recently it was considered a novelty, now it is necessary due to technological orientations that have been included in teaching. In this regard, many programs in the district of Elbasan intend to encourage computer skills in the young generation and the desire for the use of information technologies, by adding computers in schools and the using them widely, the free internet application, online learning, etc..

* Video Projector: It is a technology which is easily found in the Albanian education system. Through its usage, it is possible to present various works in teaching and scientific field.

In fact the video projector is a forerunner of the interactive board, but however, due to the conditions of our education system it remains the most advanced technology used in teaching. 
* CD-Roms: CD-ROM (Compact Disc Read Only Memory): This compact disc collects digital information; it holds this name because it does not allow modifications. It is an ideal support for the distribution of assets (computer software) or voluminous documents.

* DVD (Digital Versatile Disc) is an optical numerical disc used for storage and data collection. Was officially launched in December 1995, DVD represents the most widespread digital video format in the world, a descendant of video tape, Laserdisc and Video CD. While the successor to the DVD Video adapted to the TVHD signal is Blu-Ray. The term Digital Video Disc which means "digital video disc" has been used for a long time by the press. The official name "Digital Versatile Disc", which means "Polyvalent Numerical Disc", specifies that this support fits all numeric data types or computing. In 1999, the DVD Forum by regrouping involved community stakeholders specifies that this format can be limited to three letters, noting that the term Digital Versatile Disc remains the official name of the format. DVD marked the beginning of a new era of home cinema. At the time of VHS, the cinematography amateur generally found only films in them. While nowadays in a DVD we can find music concerts, TV series, video clips, humor shows, documentaries etc.

* The internet (Interconnected Networks): This term indicates the global network by adding computers and telecommunications resources, aimed at the exchange of electronic information and multimedia files. It uses a common protocol that allows the closest transportation of the messages separated in independent packages. This journey is based on the IP protocol (Internet Protocol) specified by the Web Association (ISOC-Internet Society). Entry to the network is open to all users who have received an address at an organization or a company. Equivalent terms used in English are: International Networking, Internet, and Net.

* Interactive Table: It is a widely advanced technology which has not yet been massively introduced in the Albanian education system, but because of the facilities, innovations and advantages that it represents, it is quite desirable for the benefit of evert teacher's work. An interactive table provides control and touch of the computer applications from the students, but also in order to enhance the classroom experience we can show anything that might be on a computer screen. This helps not only in visual learning, but also in the students' interaction because they are able to write; present different information and manipulate images on the interactive table. There are many other tools that can be used in the educational process in our schools but that also need a certain fund available. These may include: digital cameras, video cameras, interactive whiteboard tools, document cameras, projectors or LCD.

* USB: It is one of the most advanced technologies in terms of storage and transmission of tasks, projects, photos and different information, they exist in different sizes and are already an integral part of the educational reality.

\section{Overview of the high schools in the city of Elbasan}

Elbasan, including its communes has a total of 207 nine-year and high schools. There are specifically 175 9-year schools and 32 high schools. In the city of Elbasan there are 47 schools in total; of these 31 are 9-year schools (2 are private) and 16 high schools (four are private). French language is present in 20 9-year schools (7 in the city and 13 in the communes) and in 17 high schools ( 9 in the city and 8 in the communes). The foreign langauges taught in these schools are: English, French, Italian and German.

In this paper we have included in our study three high schools in the city of Elbasan, which we appreciated not only for their history and tradition in the teaching / learning of foreign languages but also for their elite teaching staff. Two of these schools are very close to each other, "F" and "E", while the other school "D" is a school that for years has been focused especially and specifically on the teaching / learning of foreign languages. The study was focused on the XI year students (ie, 2nd year) and on the teachers who provide French language in these classes for each school mentioned above.

\subsection{Overview of school $D$}

School "D", as mentioned above was selected because it has a long tradition on foreign language teaching. It is one of the elite schools of the city of Elbasan and its teachers have a wide experience in teaching foreign languages. It is also equipped with laboratories and technological tools that assist in the teaching of French as a foreign language. The school has 350 students of which 95 are students of the French language. School "D" has 17 teachers of foreign languages (English, French, Italian and German), of which four of them are teachers of the French language. In our study, as mentioned above 
we have included the XI classes XI (ie II year). The school has only one XI class, unlike other high schools, and this group consists of 32 students who have been included in our study sample.( Table 1/1)

\subsection{Overview of school $\mathrm{E}$}

School "E" was opened for the first time in September 1986 with four initial classes and year after year it has grown in number, thus completing the first Matura in 1990. It is a school with a rich tradition that carries great value in the field of education in Elbasan. The school has a total of 835 students, 181 of whom learn French as a foreign language in various classes. School (E) has seven foreign language teachers, two of whom are teachers of the French language. Class XI has a total of 50 students divided into two groups. In our sample we have selected only one group, the one which had the greatest number of students: 42 students.( Table 1/2)

\subsection{Overview of school $F$}

School "F" has currently 830 students. 175 of them learn French as a foreign language. The school has six teachers of foreign languages but only one is a French language teacher. The number of students in class XI is 54 and they are divided into two groups. We have selected in our sample only one group which is smaller compared to the two samples from the two other schools (D, E). This group is composed of only 13 students. Languages are taught from class X to class XII. The school organizes 21 hours a week of teaching in different classes. (Table 1/3)

\subsubsection{An overview of the ICT infrastructure in the high schools}

With regard to the equipment of professional labs for teaching foreign languages, we can say that there is only such lab in school "D", but even this one does not reach the latest technology standards, and it functions as a computer laboratory. While the other high schools in the city of Elbasan develop the teaching of foreign languages as normal classes similar to other subjects, and sometimes they use the computer laboratories or other ICT tools such as CD player, video projector or video connected TV.

\subsubsection{The technological infrastructure in schools $D / E / F$}

School (D), is the only one that has a foreign language lab even though it is not up to standard, and is currently converted into a computer lab. This has resulted in school (D) to have two computer rooms which are used by teachers of foreign languages based on a graph. The number of computers in these rooms is 25 in total. They have access to the Internet. School (D) does also have other ICT equipment such as: 1 video projector, two TV sets and one video, CD-Rom, DVD, and many VHS tapes with French documentaries but that are not used anymore because they have been replaced by DVD and other online resources.

School (E), has only one informatics lab available that is composed of 24 computers that are connected to the internet. The school does also have 1 video projector and a CD player.

School (F), similarly to school (D), is equipped with two computer labs which have a total of 25 computers. All computers are connected to the Internet, and students have access at all times, similarly to the two high schools mentioned above. This school has other ICT tools as well such as: 1 CD player, one TV set and a video. There are also some DVDs with materials in French. (Table 1/4)

\subsubsection{Characteristics of the sampled teachers in the high schools}

The selected teachers in our sample are of different age groups and have a work experience that start from 1 up to 27 years of teaching foreign languages. In one way or another in this study there have been included different generations of teachers.

\subsubsection{Characteristics of the teachers for schools $D / E$ / F}


Teacher (6), part of our sample is 24 years old and is the youngest compared to the others. He has 1 year of experience in teaching and works for school "D". Being the youngest, he feels closer to technologies compared to the rest of the teachers. He has participated in three trainings associated with the integration and use of ICT $s$ in foreign language teaching. He also has very good knowledge of ICT and even uses them often.

Teacher (7) is again a teacher is school (D). He is 52 years old and has 27 years of experience in the job. Despite his relatively old age, he has wide knowledge about ICT and has also participated in training in this regard.

Teacher (8) belongs to the school (D) again and is 35 years old. He has 11 years of working experience in teaching French as a foreign language. Although he has not participated in any training regarding the integration and use of ICT s in teaching foreign languages, he asserts that he is familiar with their use.

Teacher (9) of school (D) is 46 years old and has 23 years of experience in teaching. This teacher has not received any training on the use of ICT s. He even asserts that he has no knowledge about the use of ICT in teaching.

Teacher (10) is a teacher of school $(\mathrm{E})$ and is 28 years old. He has a work experience of three years and has not participated in any training regarding the integration and use of ICT s in foreign language teaching. But he claims to have knowledge about the use of ICT and in some cases he even uses them.

Teacher (11) is again from school (E). His age is 43 years old and he has 25 years of experience in the job. Has not participated in any training and does not have knowledge about the use of ICT s in foreign language teaching.

Teacher (12) is of school (F) and is 29 years old. He has six years of working experience in teaching French language. This teacher has participated in two training sessions regarding the integration and use of ICT $\mathrm{s}$ in teaching foreign languages. He has very good knowledge about the use of ICT in teaching and asserts that he uses them often.( Table 1/5)

\subsubsection{The use of ICT in the high schools}

High School (D) as a foreign language school owns two computer labs with 25 computers that are connected to the Internet. There can be found more ICT tools in this school compared to the others due to the same reason. What is more, the teachers of this school are familiar with ICT use them more frequently than the other schools. In the questionnaire addressed to the school principals (see appendices), the director of the school states that the problem is the fact that the two computer rooms are not enough to satisfy the needs of all the teachers and students of the school, because they are numerous and being a foreign languages school, the use of ICT is even more necessary compared to other schools. For this reason, constant demands have been made but the situation remains the same. However, from the completed questionnaires and the observation sessions we noticed that teachers use other ICT tools like: video projectors, recorders and TVs connected to video where students watch documentaries and films in French. They also use USB to distribute learning materials and information related to the topics of the day, DVDs and VHS tapes for documentaries and films in French. They are familiar with the IWB but the school does not have one.

High School (E), as noted above, has only one computer lab which is equipped with 24 computers that are connected to the Internet. The use of ICT is rare in foreign language teaching in this school because the teachers do not have the proper trainings or education for their integration in classes. Only one of the teachers tries to apply ICT in the teaching of French, but this happens no more than once every two weeks. From the results of the teachers' questionnaire it can be shown that the teachers mostly used the $\mathrm{CD}$ player, the video projector and computer programs with exercises using various internet sites. Other ICT tools are not used at all. They do not have information about IWB and of course do not know how to use one.

High school "F" has two computer labs, with a total of 25 computers and they also have access to the Internet. The school administration has a project of opening a specialized laboratory for foreign languages which will include all ICT tools because student and teachers altogether are interested in using them. The teacher of French uses the computer lab once a week only because the lab is used by the other teachers in the school as well. In this school the teachers seem to have a relatively good knowledge of the use of ICT s in foreign language teaching. From the questionnaires, we learned that ICT s most widely used are: CD-Rom, working on the computer (of the materials), video, video-projector, Internet programs (with exercises) and the CD player. Meanwhile the school does not use VHS tapes; the radio, the television or other purchased programs like Tell me more, TBI etc.

In connection with the frequency of ICT use in order to develop students' language skills, we can say that the situation is better compared with that of 9 -year schools. The following table shows the respective percentages by intensity.( Table 1/6) 
As a result, we can say that the most frequent use of ICT s can be found in the socio-intercultural competence by $35 \%$ and a regular use of ICT with a higher percentage can be found in the oral comprehension by $30 \%$. A lower percentage of use is found in speaking with $44.5 \%$.

Regarding the efficiency of their use, teachers and school directors have stated in their questionnaires that ICT motivate students and make the class more interesting, especially IWB, internet programs such as Tell me more, radio, TV, video projector etc.. Their use is seen as an advantage in the teaching of French as it allows students to be in contact with the French language and to benefit as much as they can in the visual aspect as well as in the auditory one.

\section{Conclusions}

At the conclusion of our research, we can state that the integration and use of ICT in the high schools of Elbasan is not yet at appropriate levels as are its counterparts in Western countries, where a special attention is devoted to the use of ICT in teaching / learning of foreign languages.

In Elbasan, although many schools are equipped with computer rooms, they are rarely used in the teaching / learning of foreign languages. This happens for various reasons, from which we can highlight the fact that many schools have only one computer lab which is used by all the teachers on the basis of a graph. Logically, a single computer lab can not meet all the needs of a school.

On the other hand it is noted that two or three students work on the same computer, this is because computers are few in number compared to the number of students per class.

What is more, the lack of a specialist or IT specialist that deals with the maintenance of the computer lab makes many computers go out of order and not be used by students and teachers anymore.

Another problem is the inadequate training of teachers in terms of integration and use of ICT in the teaching/learning of foreign languages, who do not have sufficient knowledge in the application and integration of these tools and of the new teaching methods. Fear of their use makes them to prefer traditional teaching, instead.

Finally, we would say that the lack of infrastructure in the high schools, the lack of ICT (limited number of them), malfunction of ICT tools, lack of trained teachers in the integration and use of ICT but also the lack of desire to use them, make teaching I learning of foreign languages in the city of Elbasan to stay within the traditional framework by not being consistent with the technological evolution of time and away from European standards.

\section{References}

Dieuzeide, H. (1994). Les nouvelles technologies. Outils d'enseignement. Paris: Nathan. Pg. 11.

Depover, C., Karsenti, T. et Komis, V. (2007). Enseigner avec les technologies. Favoriser les apprentissages, développer des compétences. Québec: Presses de l'Université du Québec.

Grégoire, R., Bracewell, R. et Laferrière, T. (1996). L'apport des nouvelles technologies de l'information et de la communication (NTIC) à l'apprentissage des élèves du primaire et du secondaire. Revue documentaire. RESCOL. [En ligne]. <http://www.tact.fse.ulaval.ca/fr/html/apport/apport96.html>.

Karsenti, T. (2002). Défis de l'intégration des TIC dans la formation et le travail enseignant: Perspectives et expériences nord-américaines et européennes. Politiques d'éducation et de formation, 27-42, Septembre.

Karsenti, T. et Tchameni Ngamo, S. (2009). Qu'est-ce que l'intégration pédagogique des TIC? Dans T. Karsenti (dir.), Intégration pédagogique des TIC: Stratégies d'action et pistes de réflexion (57-73). Ottawa: CRDI.

Larose, F., Grenon, V. et Lafrance, S. (2002). Pratiques et profils d'utilisation des TICE chez les enseignants d'une université. Dans R. Guir (dir.). Former les enseignants et les formateurs à de nouveaux usages (pg. 33-47). Bruxelles: De Boeck et Larcier.

Jeannine Gerbault, "TIC et diffusion du français: des aspects sociaux, affectifs et cognitifs aux politiques linguistiques" L'HARMATTAN, 2002. Fq.12.

Nicolas Guichon (2012), “Vers l'intégration des TIC dans l'enseignement des langues” fq. 5. Didier, Paris. 
Palais des Nations, Alger, samedi 13 mai 2000, marrë në artikullin e Dr. Karima Ait-Dahmane me titull "L'impact des TICE sur l'enseignement / apprentissage de la langue française dans le supérieure: quells besoins de formation pour quelle pédagogie? Fq. 228, gjendet edhe në linjë karima_ait_dahmane.pdf.

RUFFIER Cl., 2006, «Acté, acteur ou actant ? Le statut des objets techniques en sociologie» ; Sociologie des transferts de techniques et d'organisations, $N^{\circ} 1$, fq. 47.

Tables

School D

\begin{tabular}{|c|c|c|c|c|c|}
\hline School & $\begin{array}{l}\text { Students } \\
\text { French }\end{array}$ & of $\begin{array}{l}\text { Students of the } X \\
\text { Class }\end{array}$ & $\begin{array}{l}\text { XI Teachers } \\
\text { French }\end{array}$ & $\begin{array}{l}\text { of } \begin{array}{l}\text { Headmaster of the } \\
\text { school }\end{array}\end{array}$ & $\begin{array}{l}\text { Number of students in our } \\
\text { study }\end{array}$ \\
\hline$D$ & 95 & 32 & 4 & 1 & 32 \\
\hline
\end{tabular}

Table 1/ 1 : Characteristics of school D

\section{School E}

\begin{tabular}{|c|c|c|c|c|c|c|}
\hline School & $\begin{array}{l}\text { Students } \\
\text { French }\end{array}$ & $\begin{array}{l}\text { of } \begin{array}{l}\text { Students of the } \mathrm{XI} \\
\text { class }\end{array}\end{array}$ & $\begin{array}{l}\text { Teachers } \\
\text { French }\end{array}$ & of $\begin{array}{l}\text { Headmaster of } \\
\text { school }\end{array}$ & the & $\begin{array}{l}\text { Number of students in our } \\
\text { study }\end{array}$ \\
\hline$E$ & 181 & 50 & 2 & 1 & & 42 \\
\hline
\end{tabular}

Table 1/ 2: Characteristics of school E

\section{School F}

\begin{tabular}{|c|c|c|c|c|c|}
\hline School & $\begin{array}{l}\text { Students } \\
\text { French }\end{array}$ & $\begin{array}{l}\text { of Students of the XI } \\
\text { class }\end{array}$ & Teachers of French & $\begin{array}{l}\text { Headmaster of the } \\
\text { school }\end{array}$ & $\begin{array}{l}\text { Number of students in } \\
\text { our study }\end{array}$ \\
\hline$F$ & 175 & 54 & 1 & 1 & 13 \\
\hline
\end{tabular}

Table 1/ 3: Characteristics of school F

Table 1/4. The technological infrastructure in the high schools:

\begin{tabular}{|c|c|c|c|c|}
\hline Schools & $\begin{array}{l}\text { Computer labs/Language } \\
\text { laboratorikes }\end{array}$ & $\begin{array}{l}\text { Nr. } \\
\text { computers }\end{array}$ & $\begin{array}{l}\text { With/without } \\
\text { internet } \\
\text { connection }\end{array}$ & Other equipment \\
\hline School D & 2 computer labs & 25 & With internet & $\begin{array}{l}1 \text { Video-projector, } 1 \text { CD } \\
\text { player, } 2 \text { TV sets and } 1 \\
\text { video, CD-Rom, DVD, } \\
\text { (VHS). }\end{array}$ \\
\hline School E & 1 computer lab & 24 & With internet & $\begin{array}{l}1 \text { Video-projector, } 1 \mathrm{CD} \\
\text { player. }\end{array}$ \\
\hline School F & 2 computer labs & 25 & With internet & $\begin{array}{l}1 \text { CD player, } 1 \text { TV set and } \\
1 \text { video, DVD. }\end{array}$ \\
\hline
\end{tabular}

Table 1/5. Characteristics of the teachers and their ICT training 


\begin{tabular}{|c|c|c|c|c|c|}
\hline & Age & Experience & School & $\begin{array}{l}\text { Nr. of tranings on ICT } \\
\text { received }\end{array}$ & Familiarity with ICT usage \\
\hline Teacher 6 & 24 years old & 1 year & D & Three & Yes \\
\hline Teacher 7 & 52 years old & 27 years & D & One & Yes \\
\hline Teacher 8 & 35 years old & 11 years & D & None & Yes \\
\hline Teacher 9 & 46 years old & 23 years & D & None & No \\
\hline Teacher 10 & 28 years old & 3 years & E & None & Yes \\
\hline Teacher 11 & 43 years old & 25 years & $E$ & None & No \\
\hline Teacher 12 & 29 years old & 6 years & $F$ & Two & Yes \\
\hline
\end{tabular}

Table 1/6. Intensity of ICT usage in developing language competences in students.

\begin{tabular}{|l|l|l|l|l|}
\hline Competences & Never & Rarely & Often & Regularly \\
\hline Oral comprehension & $10 \%$ & $29,5 \%$ & $30,5 \%$ & $30 \%$ \\
\hline Written comprehension & $27,5 \%$ & $22,5 \%$ & $25 \%$ & $25 \%$ \\
\hline Speaking & $5 \%$ & $44,5 \%$ & $25,5 \%$ & $25 \%$ \\
\hline Writing & $14,5 \%$ & $35,5 \%$ & $25 \%$ & $25 \%$ \\
\hline $\begin{array}{l}\text { Interaction } \\
\text { Socio and intercultural } \\
\text { competences }\end{array}$ & $5 \%$ & $40,5 \%$ & $29,5 \%$ & $28 \%$ \\
\hline
\end{tabular}

